\title{
IÇ KONTROL, RISK YÖNETIMI VE KURUMSAL YÖNETIM SÜREÇLERININ DEĞERLENDIRILMESINE YÖNELIK ÖLÇEKLERIN GÜVENILIRLIK VE GEÇERLILIK ÇALIŞMASI*
}

\author{
Göksel KORKMAZ** \\ ÖZ
}

Bu çalışmanın amacı iç denetimin, temel kurumsal süreçler olan iç kontrol, kurumsal risk yönetimi ve kurumsal yönetim süreçlerini değerlendirebileceği ölçekler oluşturmak ve bu ölçeklerin güvenilirlik ve geçerliliğini test etmektir. Çalışmanın kavramsal çerçevesi iç denetim, kurumsal yönetim, iç kontrol ve risk yönetimi yazınından istifade etmek suretiyle ölçekler oluşturulmuş, Türkçeye çevrilerek adapte edilmiş ve bu ölçeklerin güvenilirliği ve geçerliliği test edilerek; kurumsal risk yönetimi, iç kontrol ve kurumsal yönetimin etkililiğinin değerlendirilebileceği ölçekler oluşturulmuştur. Çalışmada, Türkiye'nin en büyük 1000 işletmesi hedef grup olarak seçilmiş ve bu işletmelerden 299 tanesi örneklem olarak alınmak suretiyle testler gerçekleştirilmiştir. Çalışma sonucunda elde edilen ölçeklerin iç denetim ve organizasyonel süreçlerin etkililik değerlendirmelerine yönelik yapılacak çalışmalarda güvenle kullanılabileceği değerlendirilmektedir.

Anahtar Kelimeler: Iç Denetim, Kurumsal Yönetim, Kurumsal Risk Yönetimi, Iç Kontrol. Jel Kodları: $M 42$

\section{RELIABILITY AND VALIDITY STUDY OF THE SCALES FOR THE EVALUATION OF INTERNAL CONTROL, RISK MANAGEMENT AND CORPORATE GOVERNANCE PROCESSES}

\begin{abstract}
The aim of this study is to create scales by which internal audit can evaluate the corporate processes such as; internal control, corporate risk management and corporate governance and to test the reliability and validity of these scales. The conceptual framework of the study was designed with the help of the literature on internal audit, corporate governance, internal control and risk management and they were adapted to Turkish tested for reliability and validity in order to assess the effectiveness of corporate risk management, internal control and corporate governance. In the study, Turkey's biggest 1000 corporations were selected as the target group and the tests were carried out by taking 299 of these corporations as the sample. The scales obtained as a result of the study can be used safely in the studies to be conducted for the effectiveness assessments of internal audit and organizational processes.
\end{abstract}

Keywords: Internal Audit, Corporate Governance, Enterprise Risk Management, Internal Control. Jel Codes: M42

\footnotetext{
*Kabul edilmiş doktora tezinden alınmıştır. (Ankara Üniversitesi Sosyal Bilimler Enstitüsü) ** Dr. Göksel KORKMAZ, Milli Savunma Bakanlığı, korkmazgoksel@gmail.com https://orcid.org/00000002-2789-2657
} 
İç Kontrol, Risk Yönetimi ve Kurumsal Yönetim Süreçlerinin Değerlendirilmesine Yönelik Ölçeklerin Güvenilirlik ve Geçerlilik Çalışması

\section{GiRiş}

Iç denetim, Organizasyonların faaliyetlerine değer katmayı amaçlayan bağımsız güvence ve danışmanlık hizmetidir. İç denetim; işletme içindeki süreçleri, prosedürleri gözden geçiren, analiz eden, iyileştirilmesi yönünde öneriler getiren, risk analizi yapan, işletme içi ve dışı tüm çıkar gruplarına hizmet veren bir fonksiyondur (Uzun, 1997). Günümüzde iç denetim, organizasyonların tüm faaliyet ve işlemlerini kapsayan çok yönlü bilgi ve yeteneği gerektiren bir fonksiyon olarak görülmektedir. İç denetim fonksiyonu işletmenin gelişme ve büyümesine yönelik tavsiyelerde bulunarak yönetsel danışmanlık faaliyeti yürütmekte ve işletmenin maruz olduğu riskleri değerlendirerek yönetime güvence vermektedir. Uluslararası İç Denetçiler Enstitüsü (IIA), iç denetimi; "Organizasyonun tüm faaliyetlerinin etkililiğini sistematik ve disiplinli bir yaklaşımla değerlendiren bağımsız güvence ve danışmanlık hizmetidir" şeklinde tanımlamaktadır. Bağımsızlık ile kastedilen, iç denetçinin tarafsızlığını ve bağımsızığını zedeleyebilecek her türlü etkiden uzak olmasıdır (Moeller, 2009, ss. 3-4). İç denetimin uluslararası standartlarda yer alan iki temel görevi vardır. Bunlar güvence ve danışmanlık görevleridir.

Danışmanlık görevi standartlarda şu şekilde açıklanmaktadır: "Kurumun faaliyetlerine değer katmak amacıyla, herhangi bir idari sorumluluk almaksızın niteliği ve kapsamı hizmet alanlarla birlikte belirlenen istişari faaliyetler ve hizmetlerdir." Danışmanlık faaliyetleri; iş süreçleri iyileştirmesi, sürekli izleme, kontrol öz değerlendirmesi, adli konular, kurumsal yönetim ve etik eğitimleri, iç kontrol gözden geçirmeleri, iç kontrol eğitimi, bir komite veya görev gücüne katılım, yeni bir ürün veya hizmetin uygulamaya geçilmeden önce gözden geçirilmesi, risk öz değerlendirmesi şeklinde icra edilebilir (Sawyer, 2016, ss. 73-75). Güvence görevi (Denetim) iç denetçinin; bir sistem, birim, faaliyet, süreç veya fonksiyonun işleyişine ilişkin kanıtlara dayanan objektif değerlendirmesidir. Görevin kapsamı ve doğası iç denetçi tarafından belirlenmektedir. Güvence görevlerinin tarafları; fonksiyon veya süreçte görev alan süreç sahipleri, değerlendirmeyi yapan iç denetçi ve değerlendirmeyi kullanan kişi veya gruplardır. Güvence hizmeti standartlarda şu şekilde tanımlanmaktadır: "Kurumun risk yönetimi kontrol ve kurumsal yönetim süreçlerine dair bağımsız bir değerlendirme sunabilmek amacıyla delillerin objektif bir şekilde incelenmesidir." Iç denetimin temel görevi organizasyonun temel süreçleri olan kurumsal yönetim, risk yönetimi ve iç kontrol süreçlerini değerlendirmek, yönetim ve yönetim kuruluna bu süreçlere ilişkin makul güvence vermektir. Makul güvence, gerekli bilgi beceri ve tecrübeye sahip bir iç denetçinin uygun denetim tekniklerini uygulayarak kanıtlara dayalı olarak elde ettiği sonuçlardır ve \%100 yanılmaz değildir (Özbek, 2012, s. 99). İç denetçi bu değerlendirmeyi yapabilmek için birtakım ölçeklere intiyaç duyar. Bu çalışmanın amacı iç denetimin, temel kurumsal süreçler olan iç kontrol, kurumsal risk yönetimi ve kurumsal yönetim süreçlerini değerlendirebileceği ölçekler oluşturmak ve bu ölçeklerin güvenilirlik ve geçerliliğini test etmektir. Bu ölçeklerin iç denetim fonksiyonuna ilave olarak yönetim tarafından söz konusu süreçlerin değerlendirmesinde de kullanılabilecektir. 


\section{Göksel Korkmaz}

\section{TEMEL KAVRAMLAR}

\section{Kurumsal Risk Yönetimi}

Organizasyonun iç denetim fonksiyonun etkililiğini değerlendirdiği temel alanların ilki kurumsal risk yönetim sürecidir. Kurumsal Risk Yönetimi Bütün kurum çapında uygulanan, kurumu etkileyebilecek olası tüm olayların tanımlanması için tasarlanan ve kurum hedeflerinin gerçekleştirilmesine yönelik makul bir güvence sağlamak amacıyla risklerin belirlenen risk iştahı içerisinde yönetilmesini sağlayan bir süreçtir (COSO, 2013). Bu çalışmada risk kavramı finansal anlamdaki risklerden daha geniş ve kurumsal bir çerçevede ele alınmaktadır. Holton (2004) riskin söz konusu olabilmesi için iki koşulu öngörmektedir. Bunlardan birincisi bir belirsizliğin olması diğeri ise bu belirsizliğin bir kayba yol açmasıdır (Holton, 2004, s. 20). Riskin içerdiği belirsizlik zarar veya kayba yol açabileceği gibi belirsizlik aynı zamanda olumlu sonuçlar verebilecek fırsatlar da içerebilecektir. Belirsizlik geleceğin tabiatında vardır ve tüm kurumlar hedeflerini gerçekleştirme yolunda eninde sonunda muhtelif ölçülerde belirsizlikle karşılaşmak durumunda kalacaktır. Yöneticiler için en büyük zorluk da hangi ölçüde belirsizliğin kabul edilebileceğidir. Belirsizliğin yönetilmesi, hem kurumsal faaliyetleri olumsuz etkileyebilecek risklerin önlenmesi hem de ortaya çıkacak fırsatların değerlendirilmeleri açısından son derece önemlidir (Özbek, 2012, s. 237).

İşletmelerin karşılaşabileceği yüzlerce risk türü bulunabilir. Finansal riskler, operasyonel riskler, stratejik riskler, uygunluk ve yasal riskler, bilgi teknolojileri riskleri genel riskler olarak ifade edebileceğimiz risklerdir. Finansal riskler kurumun tercih ettiği finansal pozisyondan kaynaklanan risklerdir. Döviz kurlarındaki dalgalanma, faiz riski, likidite riski finansal risklere örnektir. Operasyonel riskler ise kurumun faaliyetlerinden kaynaklanan kurumu maddi ve itibar anlamında zarara uğratabilecek her türlü risktir. Stratejik riskler ise kurumun orta ve uzun vadeli hedeflerine ulaşmasını engelleyebilecek nitelikteki risklerdir. Uygunluk ve yasal riskler ise mevcut mevzuat ve düzenlemelere aykırılıklar nedeniyle maruz kalınabilecek müeyyidelere ilişkin risklerdir. Bilgi teknolojisi riskleri iş süreçlerini olumsuz etkileyebilecek, kurumu maddi veya itibari zarara uğratabilecek bilgi sistemi kaynaklı risklerdir (Sakarya ve Kara, 2012, ss. 73-75).

KRY, tüm kurum çapında bütünleşik bir şekilde uygulanmak ve riskleri kurumun risk iştahı çerçevesinde yönetmek için tasarlanmış bir süreçtir. Risk yönetimi; sürprizlere hazırıklı olmak, belirsizlik altında doğru karar vermek, işletme performansını arttırmak, rekabet avantajı sağlamak, kayıp maliyetlerini azaltmak ve varlığını sürdürmek açısından son derece önemli bir süreçtir. AICPA tarafından Fortune 500 listesindeki CEO'lar arasında 2016 yılında yapılan bir çalışmada; son beş yıl içerisinde operasyonel sürprizlere tamamen veya büyük ölçüde hazırlıksız yakalandıklarını ifade edenlerin oranı \%63, son beş yıl içerisinde karşı karşıya kalınan risklerin büyüklük ve karmaşıklığının çok büyük oranda değiştiğini ifade edenlerin oranı ise \%57'dir (AICPA, 2016, s. 16). Risklerini yönetemeyen organizasyonlar birçok olumsuzluğa hazırlıksız olarak yakalanmaktadırlar ve her yıl maruz kalınan risklerin karmaşıklığı biraz daha artmaktadır. Kurumsal Risk Yönetimi, son yıllarda önemi ve kullanımı hızla artan ve organizasyonların operasyonel sürprizlere hazırlıklı olmak için kullandıkları bir risk yönetim sürecidir. 
İç Kontrol, Risk Yönetimi ve Kurumsal Yönetim Süreçlerinin Değerlendirilmesine Yönelik Ölçeklerin Güvenilirlik ve Geçerlilik Çalışması

\section{İç Kontrol}

Organizasyonun faaliyetlerini izlemesi ve kontrol etmesinde güvenilirlik sağlayan en önemli mekanizma iç kontroldür. Faaliyetlerini belirlenen esaslara uygun ve etkin yapmak isteyen tüm organizasyonlar hataları minimize etmek için iç kontrol sistemini kullanmak zorundadır (Jones, 2008, s. 1064). Organizasyonun iç kontrollerini anlamak ve etkili bir şekilde uygulanması konusunda makul güvence vermek iç denetimin temel prensibidir. Uluslararası İç Denetçiler Enstitüsü (IIA) iç kontrolü; "Yönetim, denetim kurulu, yönetim kurulu ve diğer birimlerin, riskleri yönetmek ve belirlenen amaç ve hedeflerin gerçekleştirilme intimalini arttırmak için gerçekleştirdikleri eylemlerdir" şeklinde tanımlamaktadır (Sawyer, 2012). Etkili iş ve finansal süreçlerin temeli iç kontrollerdir ve iç denetimin temel işlevi de her seviyede kontrollerin değerlendirilmesidir. İç kontrollerin amacı değişen ekonomik ve rekabet koşullarıyla mücadele ederken organizasyonu hedeflerine ulaştırmak ve karşılaşabileceği sürprizleri minimize etmektir. İç kontroller etkinliği teşvik ederken varlıklara ilişkin kayıp riskini azaltmakta, finansal raporların güvenilirliğini arttırmakta yasa ve düzenlemelere uyum sürecine katkı sağlamaktadır.

Dünyada kullanılan en yaygın iç kontrol çerçevelerinden biri olan COSO (Comitte of Sponsoring Organizations of The Treadway Commision)modeline göre iç kontrol: "Kurumun yönetim kurulu, üst yönetimi ve diğer personeli tarafından etkilenen ve aşağıdaki hedeflerin yerine getirildiğine dair makul bir güvence sağlamak amacıyla düzenlenen bir süreçtir ve "Operasyonların etkililiği ve verimliliği,Finansal raporların güvenilirliği, Yasa ve mevzuata uyum." şeklinde tanımlanmaktadır.

Yukarıda genel tanımı yer alan COSO modeli bir organizasyonun iç kontrollerini tanımlarken üç boyutlu bir model kullanmaktadır. Küp şeklinde gösterilen bu modelin ön yüzünde iç kontrolün beş bileşeni (Kontrol ortamı, Risk değerlendirme, kontrol faaliyetleri, bilgi ve iletişim, izleme) üst yüzünde iç kontrolün hedefleri (Finansal raporlama, uyum ve operasyonların etkililiği), yan yüzünde ise kontrollerin seviyeleri (Birim ve kurum düzeyi) yer almaktadır. Tüm iç denetçiler COSO iç kontrol çerçevesini anlamalı ve hangi alanı denetlerlerse denetlesinler her seviyede iç kontrollere bakmalıdırlar (Moeller, 2009, s. 33). COSO iç kontrol modelinde en önemli unsuru insandır, süreç tüm çalışanlardan etkilendiği gibi tüm çalışanları da etkilemektedir. COSO iç kontrol çerçevesi dinamik süreçlere ve interaktif değerlendirme yapabilecek kişilere ihtiyaç göstermektedir. COSO iç kontrol çerçevesi beş bileşen 17 standart ve 77 genel şarttan oluşmaktadır. COSO'nun beş bileşeni aşağıdaki gibidir:

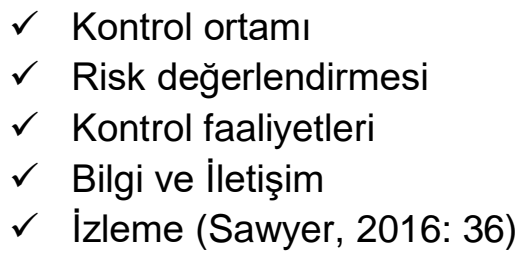

Bir kurumun iç kontrol süreci COSO çerçevesinde değerlendiriyorsa bu beş bileşene sadık kalınmalıdır. Yönetimin yeterli seviyedeki desteği iç kontrol sisteminin 


\section{Göksel Korkmaz}

etkili bir şekilde işletilmesine katkı sağlayacak olsa da bu sistem,uygulanmakta olan kontrollerin etkililiğini değerlendirecek uygun kontrol süreçleriyle desteklenmelidir. Bir kurum iç kontrollerinin etkililiğini değerlendirmek için birçok farklı izleme faaliyeti gerçekleştirmelidir. İç denetçilerin en önemli görevleri izleme sürecinin bir parçası olarak organizasyonun iç kontrollerinin etkililiğini ve verimliliğini değerlendirmektir. İzleme faaliyeti, sürekli izleme, müstakil değerlendirmeler veya her ikisinin bileşimi şeklinde uygulanmaktadır. Sürekli izleme, faaliyetin gerçekleşmesi esnasında alınan yönetsel tedbirleri kapsar. Faaliyetlere ve finansal raporlara yönelik yönetim gözden geçirmeleri, dışarıdan gelen şikâyetler ve bunlara yapılan işlemler, yazım hatalarına yönetici seviyesinde yapılan müdahaleler, suiistimale açık görevlerin farklı kişilerce yürütülmesi, envanterin fiziksel olarak kontrolü ve kayıtlarla karşılaştııılması sürekli izleme faaliyetine örnek olabilir(Moeller, 2009, s. 47).

Ayrı veya müstakil değerlendirmeler ise, belirli bir zaman dilimi içerisinde bu konuda ehil kişiler tarafından yapılan değerlendirmelerdir. Sürekli izleme faaliyeti ne kadar etkili bir şekilde gerçekleştirilirse, münferit veya ayrı değerlendirmelere o denli az intiyaç duyulur. Değerlendirme eğer belirli bir faaliyetten sorumlu kişiler tarafından yapılıyorsa öz değerlendirme adını alır. İç denetçiler de normal görevlerinin bir parçası olarak üst yöneticinin talebi doğrultusunda iç kontrol sistemini değerlendirir (Özbek, 2012, s. 448). Yönetim tüm iç kontrol sisteminin periyodik olarak değerlendirilmesini isteyebileceği gibi iç denetçiler belli riskli alanlara odaklanarak değerlendirmelerini yapabilir. COSO'ya göre iç kontrollerin gözden geçirilmesi ve değerlendirilmesi için; sistemin tasarımına ilişkin bir anlayış geliştirilmeli, anahtar kontroller test edilmeli ve bu testlere göre sonuçlara ulaşılmalıdır. COSO'nun önerdiği bir diğer yöntem ise kıyaslama (benchmarking) yöntemidir. Kıyaslamalar benzer organizasyonlar veya yayınlanan endüstri istatistiklerine göre yapılır. İç denetçiler tarafından yapılan değerlendirme neticesinde organizasyonun hedeflerine ulaşmasını etkileyebilecek tüm kontrol zafiyetleri uygun düzeltici eylemi gerçekleştirebilecek kademelere raporlanmalıdır(Moeller, 2009, s. 49).

İç denetim fonksiyonunun iç kontrol süreci içerisindeki temel rolü iç kontrollerin etkililiği ve yeterliliğini değerlendirmektir. Ancak iç denetim fonksiyonu yönetsel sorumluluk almamak koşuluyla iç kontrol süreçlerinin gelişimine destek sağlayacak süreçlerin ve çalışmaların içerisinde yer alabilir. İç denetim,COSO'nunüçlü savunma hattı olarak öngördüğü aşağıdaki çizelgede yer alan iç kontrol sistemi sorumluluk kademelerinde de 3'üncü kademede yer almaktadır(Sawyer, 2012).

Tablo 1: Üçlü Savunma Hattı

\begin{tabular}{|l|l|l|}
\hline 1.Kademe & 2.Kademe & 3.Kademe \\
\hline - Yönetim Kurulu & - Finansal Kontrol & - İç Denetim \\
- Üs Düzey Yöneticiler & - İç Kontrol Görevlileri & - Bağımsız Denetim \\
- Orta Kademe Yöneticiler & - Uygunluk Görevlileri & \\
- Çalışanlar & - Risk Yöneticileri & \\
& - Etik Görevlileri & \\
& - Kurumsal Yönetim Sorumlusu & \\
\hline
\end{tabular}

Organizasyonda iç kontrol sisteminin kurulması ve işletilmesinden birinci derecede yönetim kurulu ve üst yönetim sorumludur. Diğer yönetici ve çalışanlar kendi 
İç Kontrol, Risk Yönetimi ve Kurumsal Yönetim Süreçlerinin Değerlendirilmesine Yönelik Ölçeklerin Güvenilirlik ve Geçerlilik Çalışması

sorumlulukları çerçevesinde iç kontrole katkı sağlamaktadırlar. İkinci kademede organizasyon içerisinden kontrolle görevli birim veya fonksiyonların sorumlulukları vardır. Üçüncü kademede ise iç kontrol sisteminin etkiliği ve verimliliğini değerlendirmekten sorumlu iç denetçiler ve bağımsız denetçiler yer almaktadır (Özbek, 2012, ss. 552-554).

Sawyer, iç kontrollerin değerlendirilmesinde iç denetçiler tarafından kullanılacak kriterleri; zamanlılık, maliyet etkinlik, nedenlerin tanımlanması, uygunluk, kök nedenlerin analizi ve kontrol tasarımlarının incelenmesi şeklinde önermektedir. Kontroller olası zararları erkenden saptayabilecek şekilde olmalıdır. Kontroller maliyet etkin olmalı, sağlayacakları fayda maliyetinden daha fazla olmalıdır. Kontroller olaydan ziyade olayın kök nedenlerini ortadan kaldıracak nitelikte olmalıdır. Yönetimin planlarını gerçekleştirmeye uygun nitelikte olmalıdır. Kontrollerin tasarımı da en az uygulanması kadar önemlidir zira zaman zaman kontrolün kendisi sorunun kaynağı olabilmektedir. Bu nedenle kontrolün uygulanması değerlendirilmeden önce tasarımında bir yanlışlık olup olmadığı değerlendirilmelidir (Özbek, 2012, s. 560).

\section{Kurumsal Yönetim (Yönetişim)}

Organizasyonun iç denetim fonksiyonunun etkililiğini değerlendirdiği diğer bir süreç de çok disiplinli doğası ve üretkenlik vadeden yapısı nedeniyle günümüz iş dünyasında oldukça yaygın bir kavram haline gelen yönetişim (gonvernance) veya bazı kaynaklarda kullanılan şekliyle kurumsal yönetim (corporate governance) kurumun tüm paydaşları ile birlikte yönetimini, kurumun yönetimine ve süreçlerine katkı sağlamasını ifade etmektedir. Yirmi birinci yüzyılın başındaki Enron, Worldcom ve Parmalat gibi finansal krizler işletmelerdeki yönetişim süreci ile ilgili tartışmaların da fitilini ateşlemiştir. Esasında yönetişim kavramını kurumların yanlış yönetilmesinin yarattığını söylemek çok da yanlış olmaz. Yönetişim ekonomik krizlere karşı bir kalkan olarak tanımlanabilir. Ülkelerin yönetişim prensiplerini adapte etmelerinin temel nedeni ekonomik dalgalanmalardaki iniş ve çıkışlardaki risklerden korunmaktır (Muneeza ve Wajeeh, 2012, s. 203).

Kurumsal yönetim veya yönetişim, son yirmi yıldır literatürde popüler hale gelmiş bir kavramdır. En basit tanımıyla "organizasyonların yönetildiği ve kontrol edildiği yoldur". Bu basit tanım esasında içerisinde birçok kavramı barındırmaktadır. Bir organizasyonun esas görevi kuruluş amacını gerçekleştirebilecek performansa ulaşmaktır. Fakat aynı zamanda bu performansın ölçüleceği çerçeve içerisinde; uygun standartlara, kurallara, yasalara, yönetmeliklere, politika ve prosedürlere bağlı kalmalıdır. Organizasyon hedeflerini gerçekleştirse bile bir yasayı çiğnemesi önemli sorunlara yol açabileceği için yukarıda sayılan tüm kavramlar birlikte değerlendirilmelidir. Farklı ülkelerde ve coğrafyalarda birçok farklı kurumsal yönetim tanımına rastlamak mümkündür. OECD tarafından ortaya konulan tanıma göre: "Kurumsal yönetim, bir şirketin üst düzey yöneticileri, yönetim kurulu, hissedarları ve diğer paydaşları arasındaki ilişkiler setidir. Kurumsal yönetim aynı zamanda firmanın hedeflerinin belirlendiği, bu hedeflere ulaşmadaki performansın değerlendirilebilmesi için gerekli araçların tanımlandığı bir yapıyı ifade etmektedir" Uluslararası İç Denetçiler Enstitüsü (IIA) ise kurumsal yönetim 


\section{Göksel Korkmaz}

kavramını; "Üst yönetim, yönetim kurulu ve denetim kurulu tarafından kurumun amaçlarına ulaşmaya yönelik olarak, kurumun faaliyetlerinin raporlanması, yönlendirilmesi, yönetilmesi ve izlenmesi gayesiyle uygulanan yapı ve süreçlerin birleşimidir" şeklinde açıklamaktadır. SPK tarafından 2005 tarihinde yayımlanan Kurumsal Yönetim İlkeleri; eşitlik, şeffaflık, hesap verilebilirlik ve sorumluluk olarak ifade edilmektedir (Özbek, 2012, s.162).

Birçok kaynakta farklı tanım yer alsa da hemen hemen her tanımda ortak olan hususlar; yönetim, yönetim kurulu ve hissedarların görev tanımlarının açık bir şekilde ortaya konulması, belirlenen amaçlara ulaştıracak bir organizasyon yapısının, politika ve prosedürler ile takip ve kontrol sisteminin kurulmasıdır. Kurumsal yönetimin ana aktörleri; hissedarlar, yönetim kurulu, yönetim ve çalışanlardır. Diğer paydaşlar da yönetişim sürecinden etkilenenler olarak değerlendirilmektedir. Kurumsal fonksiyonlar sahipler veya hissedarlar tarafından görevlendirilen yöneticilerin gözetiminde yerine getirilmektedir. Yönetici kurumsal amaçları gerçekleştirecek ve piyasa beklentilerini karşılayacak kurumsal stratejiyi formulüze etmekte ve bu stratejiyi uygulamaya koyacak çalışanları istihdam etmektedir. Üst yönetim, yöneticileri gözetirken yöneticilerde diğer çalışanları gözetmektedir. Belirlenen hedefleri gerçekleştirmek için üst yöneticiler alt birimlerin hedeflerini belirler, bütçe tahsis eder ve performansı ölçecek mekanizmalar tesis ederler. Daha sonra tüm iş faaliyetleri muhasebe sistemini besler ve üst yöneticilerde bunu raporlaştırarak hissedarlara hesap verirler. Yöneticilerin esas sorumluluğu bir hizmetkâr olarak hissedarların faydasını maksimize edecek eylemleri hayata geçirmektir (Pickett, 2010, s. 25). Yöneticiler ile hissedarlar arasındaki ilişki "Vekâlet İlişkisi"dir. Bu ilişkide yöneticilerden beklenen hissedarlardan aldıkları yetkileri yine hissedarların menfaatine kullanmalarıdır. Bu noktada vekil maliyeti kavramı karşımıza çıkmaktadır. Vekil maliyeti, hissedardan aldığı yetkiyi hissedar menfaatine kullanması gereken yöneticilerin, hissedarların menfaati ile kendi menfaatleri arasında kalmasının sonuçlarıdır. Bu maliyetler doğrudan olabileceği gibi verilen kararların yansıması şeklinde dolaylı da olabilmektedir. Kurumsal yönetim yaklaşımının temelinde iki soruna çözüm bulma çabası yer almaktadır; bunlardan ilki vekil maliyetlerine, yani hissedar ve yöneticilerin motivasyon farklılıklarından kaynaklanan maliyetlerin minimize edilmesi diğeri de azınlık hisse sahiplerinin çoğunluk hisse sahipleri karşısında korunmasıdır (Özbek, 2012, ss. 166-168).

Kurumsal yönetim kavramı olumlu veya olumsuz anlamda dört temel teori ile ilişkilidir. Bunlardan ilki yukarıda bahsedilen vekâlet teorisi, diğerleri işlem maliyetleri, paydaş ve hizmetkârlık teorileridir. İşlem maliyetleri teorisine göre kurumlar beklenti ve amaçları farklı olan kişilerden kurulmuş yapılardır. Yöneticiler fırsatçıdırlar ve kendi çıkarları için kurumun verilerini manipüle edebilmektedirler. Bu teoriye göre organizasyon içerisinde dürüstlük etik değerler, yönetişim prensipleri, şeffaflık, hesap verilebilirlik ve sorumluluk ilkelerine dayanan güçlü bir yönetişim yapısının sağlanabilmesi mümkün değildir. Paydaş teorisine göre günümüz organizasyonları oldukça geniş ve büyüktür ve toplum üzerindeki etkisi de son derece önemlidir. Bu yüzden de organizasyonların yönetimi açısından yalnızca kendi hissedarlardan ziyade çıkar gruplarına karşı sorumlu olmaları gerekliliğini ortaya çıkarmaktadır. Vekâlet teorisinin aksine paydaş teorisine göre yöneticilerin; tedarikçiler, yatırımcılar, müşteriler, 
İç Kontrol, Risk Yönetimi ve Kurumsal Yönetim Süreçlerinin Değerlendirilmesine Yönelik Ölçeklerin Güvenilirlik ve Geçerlilik Çalışması

çalışanlar, hükümet ve politik gruplardan oluşan bir ağı vardır ve bu ilişkiler ağı güçlü bir yönetişim sürecini destekleyecek şekilde yönetilmektedir. Hizmetkâr teorisinin özünde yöneticilerin kurumun hizmetkârları olarak hissedar değerini ve zenginliğini maksimize edecek şekilde görevlerini azami özeni göstererek gerçekleştirmeleri vardır. Bir başka deyişle hissedarlar yöneticilerine güvenirler ve onların işlerini iyi yaparak kazançlarını maksimize edeceğine inanırlar. Her iki taraf da ortak bir amaç için çalışarak güçlü bir yönetişim sürecine katkı sağlarlar.

\section{ARAŞTIRMANIN KAPSAMI VE YÖNTEMI}

Araştırmanın ana kütlesini ISO 1000 sanayi endeksinde yer alan işletmeler oluşturmaktadır. \%95 güven aralığı ve 0,05 örneklem hatası esas alınarak 278 işletmenin örneklem büyüklüğü açısından yeterli olacağı değerlendirilmiş ve 299 işletme üzerinde çalışma yapılmıştır. Literatür taraması ile iç kontrol, kurumsal risk yönetimi ve kurumsal yönetim uygulamalarının başarısını değerlendirmek maksadıyla kullanılacak ölçekler oluşturulmuştur. 5'li likert sistemi kullanılarak anket soruları haline getirilen ölçekler işletmelerin üst yöneticilerinden alınan cevaplar çerçevesinde analiz edilmiştir. 5'li likert ölçeğinde "kesinlikle katılmıyorum" ifadesi 1 puana, "kesinlikle katılıyorum" ifadesi ise 5 puana karşılık gelmektedir. Ölçekte 1 "çok düşük”, 5 çok yüksek başarı düzeyini ifade etmektedir ve ortalamanın 5'e doğru yaklaşması başarılı bir uygulamayı ifade etmektedir.

\section{Verilerin Toplanması ve Araştırmanın Sınırlılıkları}

Araştırma yöntemi; araştırma örnekleminin belirlenmesi, anket formunun oluşturulması, anketin uygulanması ve verilerin analizinden oluşmaktadır. Araştırmanın hedef kitlesi olarak Türkiye'nin en büyük 1000 sanayi kuruluşu seçilmiştir.Araştırma için 974 işletmeden randevu talep edilmiş, 214 işletmeden ret cevabı alınmıştır. 460 işletme randevu taleplerine olumlu yanıt vermiş ve 23 işletmede yetkili kişi araştırma sorularını yarım bırakmıştır. 299 işletmede, üst yönetici pozisyonundaki yetkili kişilerle araştırma tamamlanmıştır. Araştırma tablet bilgisayarlar ile yüz yüze görüşmek suretiyle gerçekleştirilmiştir. Araştırmada elde edilen sonuçlar üst düzey yöneticilerin sorulara objektif ve doğru bir şekilde cevap verme eğilimiyle sınırlıdır. Ayrıca üst yöneticilerin iş yoğunluğu sebebiyle sorulara net cevaplar vermemesi de araştırmanın sınırlılıklarındandır.

\section{Kullanılan Ölçekler}

\section{Kurumsal Risk Yönetimi}

Yapılan inceleme ve taramalar neticesinde Kurumsal Risk Yönetim süreci uygulamalarının hangi ölçüde başarılı olduğunu değerlendirecek ve uluslararası anlamda kabul görmüş bir ölçek bulunamamıştır. Alan yazında bazı yazarlar "KRY'nin etkililiği", "KRY olgunluk seviyesi", "KRY performansı" gibi kavramlarla KRY uygulamalarının başarısını değerlendirmişlerdir.KRY'nin olgunluk seviyesi; Hilson (1997) tarafından; kültür, süreç ve deneyim boyutlarıyla, Hopkinson (2000) tarafından; 


\section{Göksel Korkmaz}

yönetim, risk tanımlama, risk analizi, risk kontrolü ve risk gözden geçirmesi boyutlarıyla, Chapman (2006) tarafından; kültür, sistem, tecrübe, eğitim, yönetim boyutlarıyla, AON tarafından; yönetim desteği, risk yöneticisi, kültür, paydaş katkısı, iletişim, finansal ve operasyonel risk bilgilerinin karar vermede kullanılması, riski değerlendirmede kullanılan araçlar, içeriden ve dışarıdan gelen risk bilgisi ve kaldıraç etkisi boyutlarıyla, Pangeram (2012) tarafından ise kültür, süreç, deneyim, uygulama ve ortaklık boyutlarıyla incelenmiştir. Yapılan çalışmalarda ortak olarak kullanılan boyutların "kültür", "organizasonel yapı" ve "yönetim süreçleri” olduğu görülmüştür. KRY uygulamalarının başarısını veya olgunluğunu değerlendirmek için organizasyonun risk kültürünün, risk hakkında paylaşılan değerler, inançlar, bilgi, tutum ve anlayışın(The Institute of Risk Management (UK), 2012, s. 12), organizasyonun riskleri yönetmek için oluşturduğu tanımlama, değerlendirme, kontrol ve raporlanmasına yönelik oluşturduğu süreçlerin ve risklerin bütünsel bir yaklaşım ile yönetilmesini sağlayacak organizasyon yapısının varlığının değerlendirilmesi gerekmektedir. Yukarıda belirtilen hususları değerlendirebilecek en uygun ölçeği tespit edebilmek maksadıyla yapılan alan yazın taramasında iki temel değerlendirme modeli ön plana çıkmıştır bunlardan ilki Monda ve Giorgino tarafından geliştirilen ve Delphi tekniği kullanılarak uygulanan "Kurumsal Risk Yönetimi Olgunluk Modeli" (Monda ve Giorgino, 2013) diğeri de RIMS (Risk Management Society) tarafından geliştirilen olgunluk modelidir (RIMS, 2011).

Monda ve Giorgino alan taramasına ilave olarak yayımlanan raporlar, uygulayıcıların tecrübeleri, danışmanlık şirketlerinin değerlendirmelerini inceleyerek; organizasyon kültürü, organizasyon yapısı ve organizasyonel süreçlerden oluşan üç boyutlu bir yaklaşım ile olgunluk seviyesini belirlenmesine yönelik bir ölçek geliştirmişlerdir. Kurumsal risklere karşı organizasyon çapında nasıl bir yaklaşım sergilenmesi gerektiğini ortaya koyan ve tüm çalışanlar tarafından paylaşılan değerler, normlar ve davranışlar olan risk kültürünün gelişmişlik ve olgunluk düzeyini gösteren temel özellikler:

- Yönetim kurulu ve üst yönetimin desteği

- KRY politikasının açıkça belirlenmesi ve çalışanlara iletilmesi

- Risk iştahı tanımın yapılması, Risklere ilişkin bilgilerin tüm organizasyon çapında paylaşılmasıve tüm hedefler için risk toleransının belirlenmesi ilgililerle paylaşılması, ortak bir risk dilinin oluşturulması

- Organizasyonun hedeflerinin, risk toleransının ve politikalarının tüm organizasyon çapında paylaşılması

- Çalışanlar için eğitim programlarının düzenlenmesi

- Risk yönetimine ilişkin teşvik mekanizmalarının oluşturulması

- Risk Yönetim sistemi ile performans yönetim sisteminin entegrasyonu

Organizasyonun risk yönetimi olgunluk düzeyinin diğer bir göstergesi de risk yönetim sürecini destekleyen bir organizasyon yapısıdır. Uygun bir organizasyon yapısı için aşağıdaki hususlar göz önünde bulundurulmalıdır:

- Risk yöneticisi olarak görevlendirme yapılması, her bir risk için tanımlamak ve yönetmekten sorumlu birim ve kişilerin belirlenmesi

- KRY'den sorumlu bir birim oluşturulması ve ekip kurulması

- KRY fonksiyonun bağımsızlığının sağlanması 
İç Kontrol, Risk Yönetimi ve Kurumsal Yönetim Süreçlerinin Değerlendirilmesine Yönelik Ölçeklerin Güvenilirlik ve Geçerlilik Çalışması

- Görev ve sorumlulukların belirlenmesi ve ilgilerle paylaşılması

- KRY sürecinin organizasyona entegrasyonunun sağlanması

- Organizasyonun her seviyedeki çalışanlarının sürece dâhil edilmesi.

Olgun ve gelişmiş bir KRY sürecini destekleyecek organizasyonel süreçler oluşturulmalı ve sürdürülebilirliği sağlanmalıdır. KRY'yi destekleyecek süreçlerin tasarımında aşağıdaki hususlar göz önünde bulundurulmalıdır:

- Organizasyonun stratejisi ve iş planları ile KRY entegre edilmelidir

- Potansiyel riskleri belirleyebilecek etkin ve etkili süreçlerin oluşturulması

- Risk kategorilerinin (finansal, operasyonel, mali vb.) belirlenmesi

- Risk değerlendirmesi yapacak formel süreçlerin tanımlanması

- Risk değerlendirme sürecinin periyodik olarak gözden geçirilmesi

- Kaynak tahsisi için risklerin önceliklendirilmesinin yapılması

- Her bir risk için yönetim stratejilerinin (kaçınma, yönetme, devretme, paylaşma) belirlenmesi, uygun durumsallık planlarının hazırlanması

- Periyodik ve sistematik bir risk raporlama sisteminin bulunması

- Risk yönetim faaliyetlerini destekleyecek nitelikte teknolojik imkânlara sahip olunması (Monda ve Giorgino, 2013, ss. 4-8).

Diğer bir olgunluk modeli olan ve RIMS tarafından geliştirilen RIMS RMM yedi nitelik ve bu niteliklere hangi ölçüde sahip olunduğunu değerlendirmekte kullanılan 25 göstergeden oluşmaktadır.

$\checkmark \quad$ KRY Tabanlı Yaklaşım:Üst yönetim ve yönetim desteğinin derecesi göz önünde bulundurulmaktadır. Yönetici pozisyonlarına terfi için risk yönetim becerisinin ön koşuldur.Farklı kademelerde günlük kararların alınması da dâhil olmak üzere risk yönetiminin öneminin farkındave organizasyonun tüm faaliyetleri ile entegre bir organizasyon kültürü hedeflenmektedir.

KRY Süreç Yönetimi: Riskin hem olumsuz sonuçlara neden olabilecek yönünü hem de fırsat olabilecek yönünü ortaya koyan, fırsatları kullanabilen, tehditleri ve belirsizlikleri ortaya koyabilen bir KRY sürecini ifade etmektedir.

Risk İştahının Yönetilmesi: Bir organizasyonun risk iştahı; arzu ettiği getiriyi elde edebilmek için almaya istekli olduğu veya kabullenebileceği risk miktarı olarak tanımlanmaktadır.

Kök Neden Analizi: Organizasyonun tüm alanlarında riskin etkilerini analiz eden bir süreç vasıtasıyla problemin kaynağını anlama, ilgili riskin veya fırsatın, gerçek kaynağını ve kontrollerin etkililiğini ölçmeye yönelen çabanın boyutunu göstermektedir.

$\checkmark$ Riskleri Ortaya Çıkarmak ve Belirlemek: Riskleri ortaya çıkarmak organizasyonun risk yönetim becerisinin özüdür. Kök neden analizi olay sonrasına odaklanırken, bu nitelik gelecekte oluşabilecek olaylara odaklanmaktadır. Bu nitelik; çalışan uzmanlığı, veri tabanları ve diğer elektronik dosyalar gibi farklı araçlardan istifade ederek risk bilgisini elde etme ve birbiriyle korelâsyonu veya bağımlılıklarını ortaya çıkarmaya odaklanmaktadır.

Performans Yönetimi-Belirsizlik Yönetimi: Organizasyonun vizyon ve stratejisini risk yönetim faaliyetleri ile birlikte yönetebilme becerisidir. Bu ancak 


\section{Göksel Korkmaz}

organizasyonel hedeflerin tüm çalışanlar tarafından benimsenmesi bu hedeflerden herhangi bir sapmanın tespit edileceğinin ve raporlanacağının bilinmesi, KRY programı ile ilgili hedeflerin organizasyonel hedefler ile uyumlu olması ile gerçekleştirilebilir.

$\checkmark \quad$ Kurumsal Esnekliğin Sürdürülebilirliği- Yüksek Sonuçlu Düşük Olasılıklı Olayların Yönetilmesi:RIMS RMM organizasyonel esnekliği; başarısızlıkları kısa sürede atlatarak değer yaratma fonksiyonunu sürdürebilmesi olarak tanımlamaktadır. Organizasyonel başarısızlıkları süratle telafi edebilme ve başarıyı sürdürebilme, bu iki beceriyi operasyonel planlama ve KRY sürecine entegre edebilme becerisini ifade etmektedir. Sürekli adaptasyon, değişen çevre koşullarına ayak uydurmada anahtar bir gerekliliktir. (Farrell ve Gallagher, 2014, ss. 631-633).

$\mathrm{Bu}$ çalışmada, yapılan alan taramasından ve yukarıda bahsi geçen iki ana modelden istifade edilerek organizasyonun kurumsal risk yönetimi uygulamalarını değerlendirebilme imkânı sağlayan bir ölçek geliştirilmiştir. Oluşturulan anket sorularına verilen cevaplar kurumsal risk yönetimi uygulamalarının başarısını ve ideal bir kurumsal yönetim yapısına yakınsamayı ifade etmektedir. 1-5 arasında yapılan puanlamadan 5 yüksek seviyede yani ideal bir kurumsal risk yönetimi uygulamasını 1 puan ise henüz uygulamaya koyulmayan veya başlangıç seviyesindeki bir KRY uygulamasını ifade etmektedir.

\section{İç Kontrol}

İç kontrol sisteminde tüm çalışanların bireysel sorumluluğu bulunsa da iç kontrol sisteminin ve iç kontrol bileşenlerin etkililiğinin değerlendirilmesi iç denetim biriminin sorumluluğundadır. İç denetçiler bu sorumluluklarını organizasyonun kullandığı iç kontrol çerçevesine uyumu değerlendirmek şeklinde gerçekleştirmektedir. Yani iç denetçiler, organizasyon tarafından uygun bulunan iç kontrol çerçevesine göre iç kontrolleri değerlendirmekte ve bu çerçeve kapsamında kontrollerin etkililiğine ve iç kontrol sisteminin geneline ilişkin yönetime makul güvence sunmaktadır. En yaygın olarak kullanılan ve IIA'ın da esas aldığı temel iç kontrol çerçevesi COSO iç kontrol çerçevesidir. $\mathrm{Bu}$ çalışmada da iç kontrol sisteminin değerlendirilmesi için bu çerçevenin bileşenleri kullanılmaktadır. COSO çerçevesine göre doğru yönetilen bir iç kontrol sistemi faaliyetlerin etkili ekonomik ve verimli yürütülmesi, finansal raporların güvenilirliği ve mevzuata uyum konusunda güvence vermektedir. COSO'ya göre bu hedefleri gerçekleştirmek için gereken iç kontrol sistemi gelişmişlik veya olgunluk seviyesi iç kontrollerin etkililiğinin de ölçüsü olarak değerlendirmektedir.

İç kontrol sistemi bileşenlerinden hangisinin bu gelişmişlik düzeyi açısından daha önemli olduğu konusunda farklı görüşler bulunmaktadır. Örneğin iç kontrolün ilk bileşeni olan kontrol ortamı iç kontrolün diğer unsurlarını etkileyen önemli bir bileşendir çünkü yönetimin etik davranışları destekleyen yaklaşımı finansal raporlamanın önüne geçebilmektedir (D’Aquila, 1998, s. 475). Aynı şekilde Sawyer (2003), Stringer ve Carry (2002) ve Simmons'da iç kontrollerin en önemli bileşeninin kontrol ortamı olduğunu ifade etmiş ve etkili bir iç kontrol sürecinin yolunun kontrol ortamından geçtiğine vurgu yapmıştır (Sawyer, 2012, s. 420). Cohen (2002) tarafından yapılan çalışma ise kontrol ortamının yalnızca yönetim açııından değil dış denetçiler açısından da en önemli bileşen olduğunu savunmaktadır. Palermo (2011)'ya göre ise organizasyon kültürü iç kontrol 
İç Kontrol, Risk Yönetimi ve Kurumsal Yönetim Süreçlerinin Değerlendirilmesine Yönelik Ölçeklerin Güvenilirlik ve Geçerlilik Çalışması

etkililiğinin temel belirleyicisidir (Palermo, 2011, s. 75).Porter ve diğerleri ise iç kontrol çerçevesinde yer alan unsurların hangisinin diğerine göre daha önemli olduğu yani unsurların birbirleri ile ilişkilerinin değerlendirilmesinin zorluğuna vurgu yapmaktadır (Porter, Simon ve Hatherly, 2003). Herman (2012) ise kontrol ortamı, risk değerlendirme ve izleme bileşenleri iyi seviyede olan kurumların iç kontrol sistemlerinin etkililiğine daha yüksek puan verdiklerini savunmuştur (Hermanson ve diğerleri, 2012, s. 38). İç kontrol bileşenlerinin birbirleri ile ilişkilerini inceleyen diğer yazarlardan Geiger (2004) kontrol ortamı ve risk değerlendirme bileşenleri arasında pozitif bir ilişkinin olduğunu, Agbejule ve Jokipii (2009) yüksek seviyede kontrol faaliyeti ve düşük seviyede izleme faaliyetinin daha etkili bir iç kontrol sistemine işaret ettiğini savunmuşlardır. (Agbejule ve Jokipii, 2009). Yine Geiger ve diğerleri (2004) tarafından kontrol zafiyetlerine yönelik yapılan çalışmaya göre; raporlanan kontrol zafiyetlerinin \%30'u kontrol faaliyetleri bileşeniyle ilgilidir (Geiger ve Cooper, 2004, s. 29). COSO tarafından 2005 yılında yapılan bir araştırma sonucuna göre ise, iç kontrolün hangi unsurunun daha önemli olduğunun belirleyicisi organizasyonun büyüklüğüdür. Büyük çaplı işletmelerde kontrol faaliyetleri bileşeni ön plandayken küçük çaplı işletmelerde daha çok izleme bileşeni ön plandadır.

İç kontrollerin etkililiği ve kontrol bileşenlerinin birbirine üstünlüğü konusunda yapılan sınırlı sayıda çalışmada farklı yazarlar farklı bileşenleri ön plana çıkarsa da mutabakat sağlanan ve hepsi tarafından üstün olduğu değerlendirilen bir bileşene rastlanmamıştır. Buradan iç kontrolün tüm bileşenlerinin aynı değerde olduğu sonucu çıkarılabilir. Bu çalışmada da organizasyonun iç kontrol sistemi açısından tüm bileşenlerin eşit önemde olduğu varsayılarak ve COSO iç kontrol çerçevesinin bileşenleri ve standartları esas alınarak iç kontrol sisteminin değerlendirilmesine ilişkin bir ölçek geliştirilmiştir. Anket sorularına verilecek 1-5 arası rakamlar vasıtasıyla iç kontrol sisteminin gelişmişlik düzeyi değerlendirilmektedir. 1 henüz tesis edilmemiş veya tesis edilmekte olan bir iç kontrol yapısını ifade ederken 5 ile yapılan değerlendirme gelişmiş ve üst seviyede bir iç kontrol yapısını ifade etmektedir.

\section{Kurumsal Yönetim}

Kurumsal yönetim uygulamalarının değerlendirilmesinde literatürde temelde iki kavram kullanılmaktadır. Bunlardan birincisi kurumsal yönetim uygulamalarının amaçlara ulaşma becerisi olarak nitelendirilen "etkililik" kavramı diğeri ise organizasyonun yeterli bir kurumsal yönetim çerçevesini kurduğunu ve bu uygulamalarda bu çerçeveye yakınsamanın, bu çerçeveye uygun hareket etmenin de başarı olarak nitelendirildiği "Olgunluk Seviyesi"dir. Bir olgunluk çerçevesine göre organizasyonun seviyesinin belirlenmesi iyi uygulama örnekleri çerçevesinde ulaşılmak istenen seviye için yapılması gerekenlerin bilinmesi sağlar. Kurumsal yönetim olgunluk seviyesi; organizasyonun uygun yönetişim yapısını, sistem ve süreçleri kurma ve yönetim kurulunun, yönetimin ve çalışanların kurulan bu yönetişim yapısı, süreçleri ve sistemlerine uyma derecesidir (Marks 2007:31; IIA 2006, ss. 4-5; Gramling ve Hermanson 2006, s. 38).Organizasyonların yönetişim olgunluk seviyesi belirlerken temelde iki problem ile karşılaşılmaktadır. Bunlardan birincisi organizasyonun yapı, 


\section{Göksel Korkmaz}

sistem, süreçlerinin mevzuat ve yasalar ile tanımlanan yönetişim yapısına uygunluğunu değerlendirebilmek için bir dizi faaliyet veya alanın değerlendirilmesi gerekliliğidir. Şüphesiz ki bu noktada belirlenecek kriterler organizasyondan organizasyona farklılık gösterebilmektedir ve bu da her yapıya uygun bir yönetişim olgunluk çerçevesini güçleştirmektedir (Bahrman, 2011). İkinci problem ise organizasyondaki yönetişim ile ilgili yapı, sistem ve süreçlerin gerçek manada uygulanıp uygulanmadığının yani yerine getirilmesi gerekenleri içeren bir kontrol listesinden farklı olup olmadığının tespitindeki güçlüktür (Wilkinson, 2014, s. 123). Ancak bu güçlüklerine rağmen yönetişim olgunluk seviyesini belirlemenin organizasyona katacağı faydalar da yadsınamaz. Kurum içerisinde kabul edilmiş bir yönetişim yapısının bulunması, rehber olarak görülen bir kriter setine sahip olunması yönetişim uygulamalarını teşvik eder. Yönetim kurulu ve yöneticiler bu ölçüm sürecine cevaben, sürekli gelişim yaklaşımı çerçevesinde organizasyonu yönetişim olgunluk çerçevesinde bir üst seviyeye çıkarabilmek için çaba sarf ederler. Ayrıca böyle bir olgunluk çerçevesi organizasyona anlık görüntü alma fırsatı tanıyarak yapılması gerekenleri ortaya koyabilmesine de katkı sağlar, zira organizasyonun nerede olduğunu bilinmiyorsa gelişmek için ne yapması gerektiğine de karar verilemez. Olgunluk modelinin bir diğer faydası da benzer alanlarda faaliyet gösteren kurumlar ile kendisini kıyaslama yapılmasına imkân sağlamasıdır. Son olarak böyle bir çerçeve organizasyonda yönetişim kültürünün oluşmasına katkı sağlar (Bahrman, 2011, s. 41-42). Kurumsal yönetim yazını incelendiğinde, kurumsal yönetime ilişkin hususların yer aldığı altı temel olgunluk modeline rastlanmaktadır. Bunlar; Rossouw ve Van Vuuren (2003) tarafından geliştirilen ve etik ile ilgili hususların değerlendirildiği Moral Yönetim Modu Modeli (Modes of Managing Morality-MMM), Açık uyum ve Etik Grubu (Open Compliance and Ethics Grup-OCEG) tarafından kurumsal yönetim merkezli kararların verilmesine yönelik olarak geliştirilen OCEG\&NACD Modeli (2007), IIA tarafından geliştirilen ve iç denetim odaklı, İç Denetim Yetenek Modeli (Internal Audit Capability Model-IA CM), RIMS tarafından geliştirilen risk odaklı Yetenek Modeli (2010), Bahrman (2011) tarafından geliştirilen ve ABD'deki iletmeler için bir çerçeve sunan GCM (Governance Capability Maturiy) Modeli ile son olarak Wilkonson tarafından (2014) geliştirilen olgunluk modelidir (Wilkinson, 2014, s. 127). Söz konusu modeller incelendiğinde Kurumsal yönetim anlamında kullanılan ortak boyutların;

- Karar verme süreçlerini de içerecek şekilde liderlik, etik kaynağı ve kültür

- Aşağıdakileri de içerecek şekilde stratejiler ve yapılar

- Yönetişim yapı ve stratejileri, Yönetim komiteleri

- Risk

- Bilgi teknolojileri

- İç denetim faaliyeti

- Yasa ve düzenlemeler

- $\quad$ Aşağıdakileri de içerecek şekilde süreçler

- Risk yönetim süreci

- İç kontrol süreci

- Etik yönetim süreci

- Performans yönetim ve ölçüm süreçleri 
İç Kontrol, Risk Yönetimi ve Kurumsal Yönetim Süreçlerinin Değerlendirilmesine Yönelik Ölçeklerin Güvenilirlik ve Geçerlilik Çalışması

- Paydaş ilişkileri yönetim süreci

- IIletişim ve raporlama(Wilkinson, 2014, s. 150)

Yukarıda belirtilen değişkenler çerçevesinde Wilkinson tarafından oluşturulan kurumsal yönetim olgunluk modeli esas alınarak, organizasyonun ideal bir kurumsal yönetim yapısına yakınsaması için sahip olması gereken temel nitelikler soru formu haline getirilerek organizasyonların kurumsal yönetim seviyesini belirlemekte kullanılmak üzere Anket formuna dâhil edilmiştir. Hazırlanan sorular en üst seviyede bir olgunluk seviyesini ifade etmekte olup 1 ile 5 arasında verilen puanlar ideale ne kadar yaklaştığını ifade etmektedir.

\section{BULGULAR}

\section{Katılımcıların Demografik Özellikleri}

Araştırma, yukarıda da belirtildiği gibi ISO 1000 listesinde yer alan Türkiye'nin en büyük sanayi kuruluşlarından 299 tanesinde üst yönetici pozisyonundaki kişilerle yüz yüze görüşmek suretiyle gerçekleştirilmiştir. Araştırmaya katılanların \% 18'i kadın, \% 82'si erkektir. Katıımcıların \%39'u 31-40 yaş arasındadır. Katılımcıların çoğunluğunu imalat (\% 44,1) ve Finans (\% 20.4) sektöründe faaliyet gösteren firma temsilcileri oluşturmaktadır. Araştırmaya katılanların \% 49.5'i 6-10 yıldır aynı firmada görev almaktadır. Ayrıca araştırmaya katılanların \% 12'si genel müdür, \% 40'ı departman müdürü ve \% 43.1'i de yönetim kurulu üyesi, yatırımcı ilişkileri müdürü ve genel müdür yardımcısı gibi diğer üst seviye yöneticilerden oluşmaktadır. Araştırmaya katılanların demografik özelliklerine ilişkin detaylı çizelge Tablo-1'de sunulmuştur. 
Göksel Korkmaz

Tablo 2. Katılımcıların Demografik Özellikleri

\begin{tabular}{|c|c|c|c|}
\hline Değişken & Grup & Frekans & Yüzde (\%) \\
\hline \multirow{2}{*}{ Cinsiyet } & Kadın & 54 & 18,1 \\
\hline & Erkek & 245 & 81,9 \\
\hline \multirow{4}{*}{ Yaş } & $20-30$ & 51 & 17,1 \\
\hline & $31-40$ & 117 & 39,1 \\
\hline & $41-50$ & 81 & 27,1 \\
\hline & 51 ve Üzeri & 50 & 16,7 \\
\hline \multirow{10}{*}{ Sektör } & İmalat & 132 & 44,1 \\
\hline & Finans & 61 & 20,4 \\
\hline & Bilişim & 10 & 3,3 \\
\hline & Lojistik & 2 &, 7 \\
\hline & Telekomünikasyon & 2 &, 7 \\
\hline & Turizm & 7 & 2,3 \\
\hline & Sağlık & 4 & 1,3 \\
\hline & Otomotiv & 6 & 2,0 \\
\hline & Enerji & 25 & 8,4 \\
\hline & Diğer & 50 & 16,7 \\
\hline \multirow{5}{*}{$\begin{array}{c}\text { Mevcut iş yerinde çalışma } \\
\text { Süresi }\end{array}$} & $1-5 \mathrm{yıl}$ & 71 & 23,7 \\
\hline & $6-10$ yıl & 148 & 49,5 \\
\hline & $11-15$ yıl & 47 & 15,7 \\
\hline & 16-20 yıl & 15 & 5,0 \\
\hline & 21 yıl ve üzeri & 18 & 6,0 \\
\hline \multirow{5}{*}{ Toplam Mesleki Tecrübe } & $1-5 \mathrm{yll}$ & 38 & 12,7 \\
\hline & $6-10$ yıl & 147 & 49,2 \\
\hline & $11-15 \mathrm{yıl}$ & 56 & 18,7 \\
\hline & 16-20 yıl & 31 & 10,4 \\
\hline & 21 yıl ve üzeri & 27 & 9,0 \\
\hline \multirow{4}{*}{ Pozisyon } & Genel Müdür & 36 & 12,0 \\
\hline & Genel Müdür Yardımcısı & 14 & 4,7 \\
\hline & Departman Müdürü & 120 & 40,1 \\
\hline & Diğer & 129 & 43,1 \\
\hline \multirow{4}{*}{ Eğitim Durumu } & Lise & 2 & ,7 \\
\hline & Ön lisans & 8 & 2,7 \\
\hline & Lisans & 191 & 63,9 \\
\hline & Lisansüstü & 98 & 32,8 \\
\hline \multirow{3}{*}{ Organizasyonun Büyüklüğü } & 0-249 kişi & 161 & 53,8 \\
\hline & 250-999 kişi & 124 & 41,5 \\
\hline & 1000-9.999 kişi & 14 & 4,7 \\
\hline \multirow{5}{*}{$\begin{array}{l}\text { Organizasyondaki ìç } \\
\text { Denetçi Sayısı }\end{array}$} & Bulunmamaktadır & 9 & 3,0 \\
\hline & $1-3$ kişi & 183 & 61,2 \\
\hline & 4-10 kişi & 77 & 25,8 \\
\hline & 11 ve üzeri kişi & 30 & 10,0 \\
\hline & Toplam & 299 & 100,0 \\
\hline
\end{tabular}

\section{Geçerlilik ve Güvenilirlik Analiz Sonuçları}

Faktör analizi, birbirleriyle ilişkili çok sayıda maddelerin bir araya getirilerek, birbirleri ile tutarlı daha az sayıda faktör elde etmeyi amaçlayan ve çok sayıda değişkenin birkaç temel değişkenle ifade edilip edilemeyeceğini araştıran çok değişkenli analizlerin genel adıdır. İki temel faktör analiz yönteminden ilki olan "Açımlayıcı" veya bazı kaynaklardaki adıyla Keşfedici Faktör Analizi, ölçek geliştirme çalışmalarının ilk aşamalarında kullanılan ve ele alınan çok sayıdaki değişkeni daha az sayıda ve açıklama gücü yüksek değişkenlere indirgemeyi hedef almaktadır. Doğrulayıcı Faktör Analizi ise daha önce kullanılmış bir ölçek veya modelin veya yeni oluşturulan bir modelin doğruluğunu teyit etmek maksadıyla kullanılır (Gürbüz ve Şahin, 2016, s. 309). Bu çalışmada kullanılan ölçeklerin tümü Türkiye'de ilk defa kullanılan ölçekler olması nedeniyle tüm ölçeklerin geçerlilikleri Açımlayıcı ve Doğrulayıcı Faktör Analizleri ile güvenirliği ise Cronbach Alfa iç tutarlılık katsayısı hesaplanarak incelenmiştir. 
İç Kontrol, Risk Yönetimi ve Kurumsal Yönetim Süreçlerinin Değerlendirilmesine Yönelik Ölçeklerin Güvenilirlik ve Geçerlilik Çalışması

\section{Kurumsal Risk Yönetimi Ölçeğinin Geçerliğinin ve Güvenirliğinin İncelenmesi}

Kurumsal Risk Yönetimi Ölçeğinin geçerliği Açımlayıcı (AFA) ve doğrulayıcı (DFA) faktör analizi ile güvenirliği ise Cronbach Alfa iç tutarlılık katsayısı hesaplanarak incelenmiştir. AFA gerçekleştirilmeden önce faktör analizi için gerekli varsayımlar kontrol edilmiştir. Bunun için örneklem büyüklüğü ve çok değişkenli normal dağıım varsayımlarının karşılanıp karşılanmadığı incelenmiştir. Örneklemin büyüklüğünü incelemek için Kaiser-Meyer-Olkin (KMO) katsayısı hesaplanmış ve KMO katsayısı 0,92 olarak bulunmuştur. Buna göre, faktör analizi için örneklem büyüklüğünün yeterli olduğu anlaşılmıştır. Daha sonra, çok değişkenli normal dağılım varsayımı incelenmiştir. Bartlett testi katsayısı hesaplanmış ve elde edilen katsayının anlamlı olduğu görülmüştür $\left(X^{2}=\right.$ $2020,21 ; p<0,001)$. Bu sonuca göre, evren parametresinde çok değişkenli normal dağılım varsayımının da karşılandığı anlaşılmıştır.

Faktör analizi için gerekli varsayımlar karşılandıktan sonra analiz gerçekleştirilmiştir. Faktör analizi sonucunda öz-değeri 1 'in üzerinde üç faktörün oluştuğu gözlenmiştir. Diğer yandan, öz-değer faktör grafiğinde birinci faktörden sonra sert bir düşüşün olduğu belirlenmiştir ve birinci faktörden sonraki faktörlerin varyansa katkısının oldukça sınırlı olduğu anlaşımıştır. Birinci faktörün öz-değeri, ikinci faktörün öz-değerinin yaklaşık altı katı olduğu gözlenmiştir. Bu sonuçlar ölçeğin tek faktörlü olduğunu işaret etmiştir. Bu aşamadan sonra, faktör analizi tek faktörlü olarak tekrar gerçekleştirilmiştir. Faktör analizi sonucunda faktör yük değeri ve binişik olma durumu birlikte değerlendirilerek sadece bir madde (m71- Potansiyel risk ve nasıl yönetileceğini de içeren bir risk kütüğü bulunmaktadır) ölçekten çıkarılmıştır. Kurumsal Risk Yönetimi ölçeğinin faktör yapısı ve ölçekte bulunan maddelere ait faktör yükleri Tablo 2'de gösterilmiştir. 
Göksel Korkmaz

Tablo 3: Kurumsal Risk Yönetimi Ölçeğinin Faktör Yapısı

\begin{tabular}{ccccc}
\hline Faktör & Madde No & $\begin{array}{c}\text { Faktör } \\
\text { Yükü }\end{array}$ & $\begin{array}{c}\text { Açıklanan Varyans } \\
\text { (\%) }\end{array}$ & Cronbach Alfa \\
\hline & $\mathrm{m} 57$ & 0,728 & \\
$\mathrm{~m} 72$ & 0,698 & \\
$\mathrm{~m} 73$ & 0,698 & \\
$\mathrm{~m} 58$ & 0,694 & \\
& $\mathrm{~m} 56$ & 0,685 & \\
& $\mathrm{~m} 59$ & 0,656 & \\
Kurumsal Risk Yönetimi & $\mathrm{m} 54$ & 0,605 & \\
(Öz-değer=6,98) & $\mathrm{m} 74$ & 0,598 & \\
& $\mathrm{~m} 55$ & 0,582 & \\
& $\mathrm{~m} 62$ & 0,577 & \\
& $\mathrm{~m} 66$ & 0,575 & \\
& $\mathrm{~m} 67$ & 0,556 & \\
& $\mathrm{~m} 68$ & 0,551 & \\
& $\mathrm{~m} 63$ & 0,538 & \\
& $\mathrm{~m} 64$ & 0,528 & \\
& $\mathrm{~m} 61$ & 0,511 & \\
& $\mathrm{~m} 69$ & 0,504 & \\
& $\mathrm{~m} 60$ & 0,501 & \\
& $\mathrm{~m} 70$ & 0,459 & \\
& $\mathrm{~m} 65$ & 0,455 & \\
\hline
\end{tabular}

AFA sonucunda, Kurumsal Risk Yönetimi ölçeğinde bulunan maddelerin faktör yüklerinin 0,728 ile 0,455 arasında değişen değerler aldığı gözlenmiştir. Tek faktörlü ölçeğe ait öz değer 6,98 olarak hesaplanmıştır. Ölçeğin tek faktörlü yapısının toplam varyansın \%34,89'unu açıkladığı belirlenmiştir. Tek faktörlü ölçeklerde açıklanan varyansın \%30 ve daha fazla olması yeterli görülmektedir(Büyüköztürk, 2006).Kurumsal Risk Yönetimi Ölçeğinin güvenirliğini belirlemek için Cronbach alfa iç tutarlııı katsayısı hesaplanmış ve incelenmiştir. Ölçeğin geneline ait Cronbach Alfa iç tutarlııı katsayısı 0,90 olarak hesaplanmıştır. Bu araştırmada Kurumsal Risk Yönetimi ölçeği için hesaplanan Cronbach alfa katsayısı, ölçeğin iç tutarlılığa bağlı güvenirliğinin yeterli düzeyde olduğunu göstermiştir. Kurumsal Risk Yönetimi Ölçeğinin açımlayıcı faktör analizi ile keşfedilen tek faktörlü yapısı DFA ile test edilmiştir. DFA sonucunda modelin eldeki verilerle ne derece uyumlu olduğunu bulmak için bazı uyum değerleri hesaplanmış ve incelenmiştir (Tablo 3).

Tablo 4: Kurumsal Risk Yönetimi Ölçeğinin Tek Faktörlü Yapısına Ait Uyum Değerleri

\begin{tabular}{|c|c|c|c|c|c|}
\hline Ölçüt & $\begin{array}{l}\text { İyi } \\
\text { Uyum }\end{array}$ & $\begin{array}{c}\text { Kabul } \\
\text { Edilebilir } \\
\text { Uyum }\end{array}$ & $\begin{array}{c}\text { Modelin } \\
\text { Uyum } \\
\text { Değerleri }\end{array}$ & $\begin{array}{l}\text { Uyum } \\
\text { Durumu }\end{array}$ & Kaynak \\
\hline$\left(x^{2} / s d\right)$ & $\leq 3$ & $\leq 4-5$ & 1,51 & İyi uyum & Byrne, 1989 \\
\hline RMSEA & $\leq 0,05$ & $0,06-0,08$ & 0,04 & İyi uyum & \multirow{2}{*}{ Browne ve Cudeck, 1993} \\
\hline SRMR & $\leq 0,05$ & $0,06-0,08$ & 0,05 & İyi uyum & \\
\hline CFI & $\geq 0,96$ & $0,90-0,95$ & 0,96 & İyi uyum & McDonald ve Marsh, 1990 \\
\hline PClose & $>0,05$ & $0,01-0,05$ & 0,91 & İyi uyum & $\begin{array}{c}\text { MacCallum, Browne ve } \\
\text { Sugawara, } 1996\end{array}$ \\
\hline GFI & $\geq 0,90$ & $0,89-0,85$ & 0,93 & İyi uyum & \multirow{2}{*}{$\begin{array}{c}\text { Tanaka ve Huba, 1985; } \\
\text { Jöreskog ve Sörbom, } 1984\end{array}$} \\
\hline AGFI & $\geq 0,90$ & $0,89-0,80$ & 0,90 & İyi uyum & \\
\hline
\end{tabular}


İç Kontrol, Risk Yönetimi ve Kurumsal Yönetim Süreçlerinin Değerlendirilmesine Yönelik Ölçeklerin Güvenilirlik ve Geçerlilik Çalışması

Tablo incelendiğinde, tek faktörlü modelin, eldeki veriler ile iyi düzeyde uyum gösterdiği anlaşılmaktadır. Test edilen tek faktörlü model şekil 1'de gösterilmiştir. Ölçekte bulunan maddelerin faktör yükleri 0,43-0,68 arasında değerler almıştır. Modelde gösterilen tüm yol katsayıları istatistiksel olarak anlamlıdır $(p<0,001)$. Sonuç olarak, Kurumsal Risk Yönetimi Ölçeğinin tek faktörlü yapısının eldeki veriler ile uyumlu olduğu anlaşılmıştır.

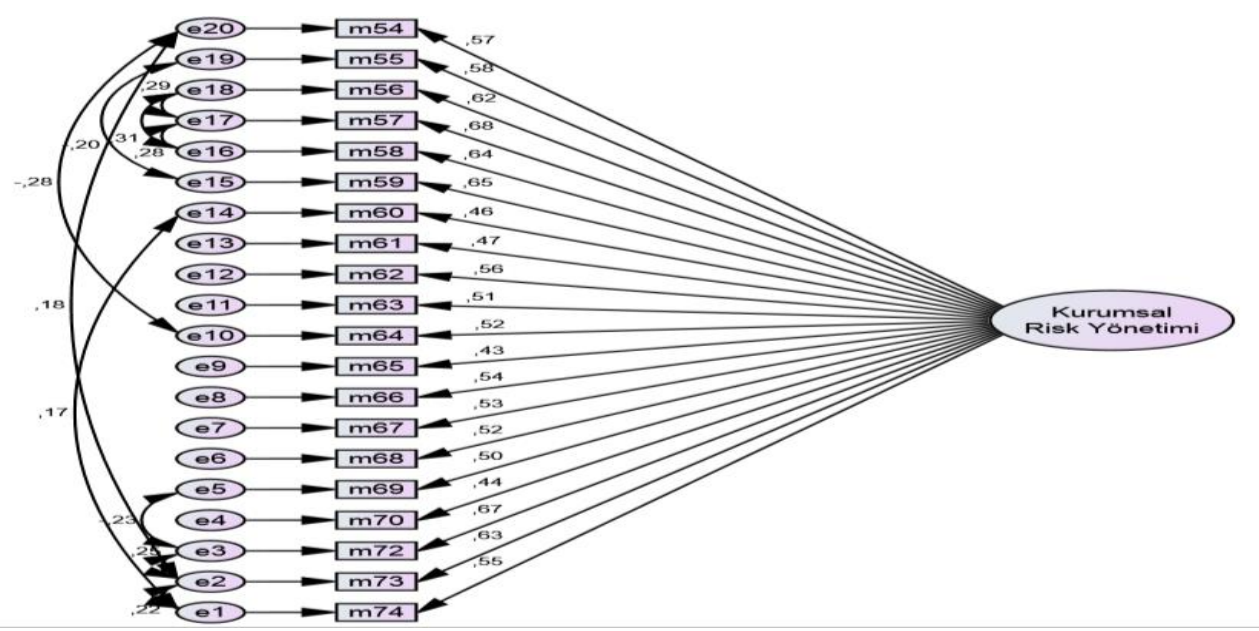

\section{Şekil-1 Kurumsal Risk Yönetimi Ölçeğine ait Doğrulayıcı Faktör Analizi Diyagramı}

\section{İç Kontrol Sistemi Ölçeğinin Geçerliğinin ve Güvenirliğinin İncelenmesi}

İç Kontrol Sistemi Ölçeğinin geçerliği Açımlayıcı (AFA) ve doğrulayıcı (DFA) faktör analizi ile güvenirliği ise Cronbach Alfa iç tutarlııı katsayısı hesaplanarak incelenmiştir. Kaiser-Meyer-Olkin (KMO) katsayısı hesaplanmış ve KMO katsayısı 0,91 olarak bulunmuştur. Buna göre, faktör analizi için örneklem büyüklüğünün yeterli olduğu anlaşılmıştır. Çok değişkenli normal dağılım varsayımı içinBartlett testi katsayısı hesaplanmış ve elde edilen katsayının anlamlı olduğu görülmüştür $\left(X^{2}=1162,93\right.$; $p<0,001)$. Bu sonuca göre, evren parametresinde çok değişkenli normal dağılım varsayımının da karşılandığı anlaşımıştır.Faktör analizi sonucunda öz-değeri 1 'in üzerinde dörtfaktörünoluştuğu gözlenmiştir. Diğer yandan, öz-değer faktör grafiğinde birinci faktörden sonra sert bir düşüşün olduğu belirlenmiştir ve birinci faktörden sonraki faktörlerin varyansa katkısının oldukça sınırlı olduğu anlaşıımıştır. Birinci faktörün özdeğeri, ikinci faktörün öz-değerininyaklaşık beş katı olduğu gözlenmiştir. Bu sonuçlar ölçeğin tek faktörlü olduğunu işaret etmiştir. Bu aşamadan sonra faktör analizi tek faktörlü olarak tekrar gerçekleştirilmiştir. Faktör analizi sonucunda faktör yük değeri ve binişikolma durumu birlikte değerlendirilerek bir madde (m84-l̇ç kontrol sistemini büyük ölçüde etkileyebilecek önemli değişikliklerin kurumu etkileme potansiyeli sürekli değerlendirilmektedir) ölçekten çıkarılmıştır. İçKontrol Sistemi ölçeğinin faktör yapısı ve ölçekte bulunan maddelere ait faktör yükleri Tablo-4'de gösterilmiştir. 
Göksel Korkmaz

Tablo 5. İç Kontrol Sistemi Ölçeğinin Faktör Yapısı

\begin{tabular}{lcccc}
\hline Faktör & Madde No & Faktör Yükü & Açıklanan Varyans (\%) & Cronbach Alfa \\
& & & \\
\hline $\mathrm{m} 78$ & 0,617 & \\
& $\mathrm{~m} 82$ & 0,597 & \\
& $\mathrm{~m} 83$ & 0,596 & \\
& $\mathrm{~m} 79$ & 0,585 & \\
& $\mathrm{~m} 89$ & 0,579 & \\
İç Kontrol Sistemi & 0,578 & \\
(Öz-değer=5,17) & $\mathrm{m} 87$ & 0,568 & \\
& $\mathrm{~m} 91$ & 0,566 & \\
& $\mathrm{~m} 76$ & 0,546 & \\
& $\mathrm{~m} 77$ & 0,546 & \\
& $\mathrm{~m} 82$ & 0,538 & \\
& $\mathrm{~m} 88$ & 0,535 & \\
& $\mathrm{~m} 86$ & 0,522 & \\
& $\mathrm{~m} 90$ & 0,503 & \\
& $\mathrm{~m} 80$ & 0,502 & \\
& $\mathrm{~m} 81$ & 0,496 & \\
& $\mathrm{~m} 85$ & 0,476 & \\
\hline
\end{tabular}

AFA sonucunda, İç Kontrol Sistemi ölçeğinde bulunan maddelerin faktör yüklerinin 0,617 ile 0,476 arasında değişen değerler aldığı gözlenmiştir. Tek faktörlü ölçeğe ait öz değer 4,84 olarak hesaplanmıştır. Ölçeğin tek faktörlü yapısının toplam varyansın \%30,41'ini açıkladığı belirlenmiştir. İç Kontrol Sistemi ölçeğinin güvenirliğini belirlemek için Cronbach alfa iç tutarlılık katsayısı hesaplanmış ve incelenmiştir. Ölçeğin geneline ait Cronbach Alfa iç tutarlılık katsayısı 0,86 olarak hesaplanmıştır. Bu araştırmada İç Kontrol Sistemi ölçeği için hesaplanan Cronbach alfa katsayısı, ölçeğin iç tutarlılığa bağlı güvenirliğinin yeterli düzeyde olduğunu göstermiştir.

Bu çalışmada İç Kontrol Sistemi ölçeğinin açımlayıcı faktör analizi ile keşfedilen tek faktörlü yapısı DFA ile test edilmiştir. DFA sonucunda modelin eldeki verilerle ne derece uyumlu olduğunu bulmak için bazı uyum değerleri hesaplanmış ve incelenmiştir (Tablo 5).

Tablo 6. İç Kontrol Sistemi Ölçeğinin Tek Faktörlü Yapısına Ait Uyum Değerleri

\begin{tabular}{|c|c|c|c|c|c|}
\hline Ölçüt & İyi Uyum & $\begin{array}{l}\text { Kabul } \\
\text { Edilebilir } \\
\text { Uyum }\end{array}$ & $\begin{array}{l}\text { Modelin } \\
\text { Uyum } \\
\text { Değerleri }\end{array}$ & $\begin{array}{l}\text { Uyum } \\
\text { Durumu }\end{array}$ & Kaynak \\
\hline$\left(x^{2} / s d\right)$ & $\leq 3$ & $\leq 4-5$ & 1,29 & İyi uyum & Byrne, 1989 \\
\hline RMSEA & $\leq 0,05$ & $0,06-0,08$ & 0,03 & İyi uyum & \multirow{2}{*}{ Browne ve Cudeck, 1993} \\
\hline SRMR & $\leq 0,05$ & $0,06-0,08$ & 0,04 & Iyi uyum & \\
\hline CFI & $\geq 0,96$ & $0,90-0,95$ & 0,97 & İyi uyum & McDonald ve Marsh, 1990 \\
\hline PClose & $>0,05$ & $0,01-0,05$ & 0,99 & İyi uyum & $\begin{array}{l}\text { MacCallum, Browne ve } \\
\text { Sugawara, } 1996\end{array}$ \\
\hline GFI & $\geq 0,90$ & $0,89-0,85$ & 0,94 & İyi uyum & \multirow{2}{*}{$\begin{array}{c}\text { Tanaka ve Huba, 1985; } \\
\text { Jöreskog ve Sörbom, } \\
1984\end{array}$} \\
\hline AGFI & $\geq 0,90$ & $0,89-0,80$ & 0,93 & İyi uyum & \\
\hline
\end{tabular}

Tablo incelendiğinde, tek faktörlü modelin, eldeki veriler ile iyi düzeyde uyum gösterdiği anlaşılmaktadır. Test edilen tek faktörlü model şekil 2'de gösterilmiştir. Ölçekte bulunan maddelerin faktör yükleri $0,43-0,60$ arasında değerler almıştır. Modelde gösterilen tüm yol katsayıları istatistiksel olarak anlamlıdır $(p<0,001)$. Sonuç olarak, İç 
İç Kontrol, Risk Yönetimi ve Kurumsal Yönetim Süreçlerinin Değerlendirilmesine Yönelik Ölçeklerin Güvenilirlik ve Geçerlilik Çalışması

Kontrol Sistemi ölçeğinin tek faktörlü yapısının eldeki veriler ile uyumlu olduğu anlaşılmıştır.

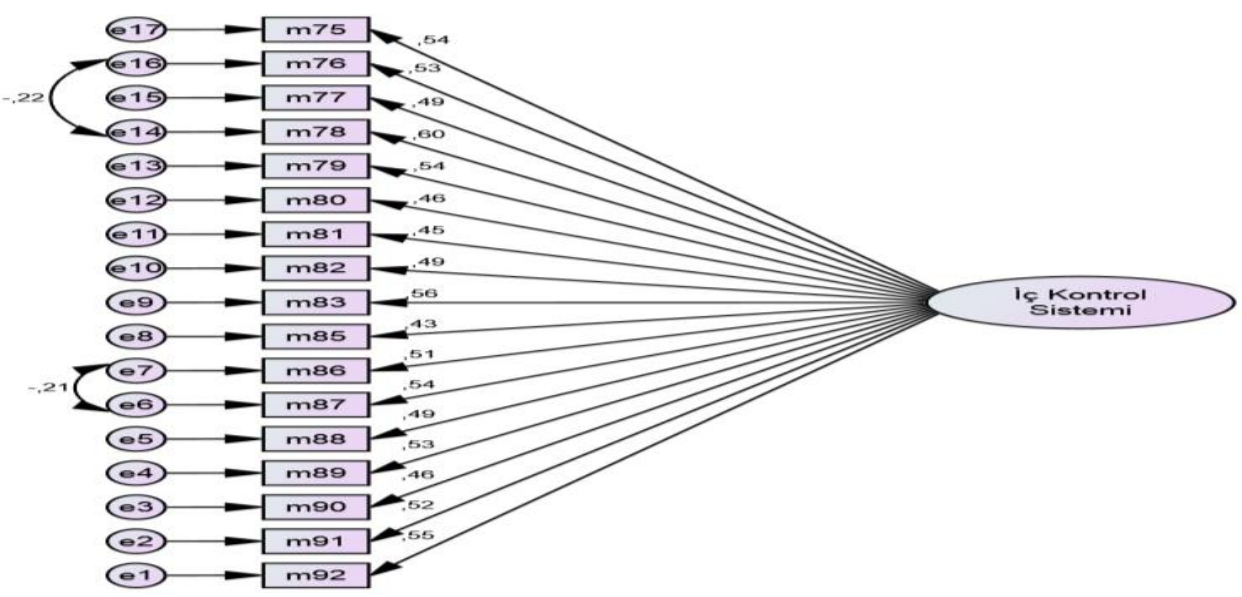

\section{Şekil-2 İç Kontrol Sistemi Ölçeğine ait Doğrulayıcı Faktör Analizi Diyagramı}

\section{Kurumsal Yönetim Ölçeğinin Geçerliğinin ve Güvenirliğinin İncelenmesi}

Kurumsal Yönetim Ölçeğinin örneklemin büyüklüğünü incelemek için KaiserMeyer-Olkin (KMO) katsayısı hesaplanmış ve KMO katsayısı 0,92 olarak bulunmuştur. Buna göre, faktör analizi için örneklem büyüklüğünün yeterli olduğu anlaşılmıştır. Daha sonra, çok değişkenli normal dağılım varsayımı için Bartlett testi katsayısı hesaplanmış ve elde edilen katsayının anlamlı olduğu görülmüştür $\left(X^{2}=1267,33 ; p<0,001\right)$. Bu sonuca göre, evren parametresinde çok değişkenli normal dağılım varsayımının da karşılandığı anlaşılmıştır.

Faktör analizi sonucunda öz-değeri 1'in üzerinde üç faktörün oluştuğu gözlenmiştir. Diğer yandan, öz-değer faktör grafiğinde birinci faktörden sonra sert bir düşüşün olduğu belirlenmiştir ve birinci faktörden sonraki faktörlerin varyansa katkısının oldukça sınırlı olduğu anlaşılmıştır. Birinci faktörün öz-değeri, ikinci faktörün öz-değerinin yaklaşık 5 katı olduğu gözlenmiştir. Bu sonuçlar ölçeğin tek faktörlü olduğunu işaret etmiştir. Bu aşamadan sonra, faktör analizi tek faktörlü olarak tekrar gerçekleştirilmiştir. Kurumsal Yönetim ölçeğinin faktör yapısı ve ölçekte bulunan maddelere ait faktör yükleri Tablo 6 'da gösterilmiştir. 
Göksel Korkmaz

Tablo 7. Kurumsal Yönetim Ölçeğinin Faktör Yapısı

\begin{tabular}{ccccc}
\hline Faktör & Madde No & Faktör Yükü & Açıklanan Varyans (\%) & Cronbach Alfa \\
& & & \\
& $\mathrm{m} 94$ & 0,632 & & \\
& $\mathrm{~m} 100$ & 0,629 & \\
& $\mathrm{~m} 101$ & 0,614 & \\
& $\mathrm{~m} 110$ & 0,599 & \\
& $\mathrm{~m} 99$ & 0,591 & \\
Kurumsal & $\mathrm{m} 108$ & 0,589 & \\
Yönetim (Öz- & $\mathrm{m} 106$ & 0,576 & \\
değer=5,66) & $\mathrm{m} 95$ & 0,56 & \\
& $\mathrm{~m} 109$ & 0,56 & \\
& $\mathrm{~m} 93$ & 0,559 & \\
& $\mathrm{~m} 96$ & 0,553 & \\
& $\mathrm{~m} 98$ & 0,541 & \\
& $\mathrm{~m} 103$ & 0,535 & \\
& $\mathrm{~m} 104$ & 0,528 & \\
& $\mathrm{~m} 105$ & 0,526 & \\
& $\mathrm{~m} 107$ & 0,518 & \\
& $\mathrm{~m} 97$ & 0,477 & \\
$\mathrm{~m} 102$ & 0,477 & \\
\hline
\end{tabular}

AFA sonucunda, Kurumsal Yönetim ölçeğinde bulunan maddelerin faktör yüklerinin 0,632 ile 0,477 arasında değişen değerler aldığı gözlenmiştir. Tek faktörlü ölçeğe ait öz değer 5,66 olarak hesaplanmıştır. Ölçeğin tek faktörlü yapısının toplam varyansın \%31,46'sını açıkladığı belirlenmiştir. Tek faktörlü ölçeklerde açıklanan varyansın \%30 ve daha fazla olması yeterli görülmektedir. Kurumsal Yönetim Ölçeğinin güvenirliğini belirlemek için Cronbach alfa iç tutarlılık katsayısı hesaplanmış ve incelenmiştir. Ölçeğin geneline ait Cronbach Alfa iç tutarlııı katsayısı 0,87 olarak hesaplanmıştır. Bu araştırmada Kurumsal Yönetim ölçeği için hesaplanan Cronbach alfa katsayısı, ölçeğin iç tutarlılığa bağlı güvenirliğinin yeterli düzeyde olduğunu göstermiştir.Kurumsal Yönetim ölçeğinin açımlayıcı faktör analizi ile keşfedilen tek faktörlü yapısı DFA ile test edilmiştir. DFA sonucunda modelin eldeki verilerle ne derece uyumlu olduğunu bulmak için bazı uyum değerleri hesaplanmış ve incelenmiştir (Tablo 7).

\section{Tablo 8. Kurumsal Yönetim Ölçeğinin Tek Faktörlü Yapısına Ait Uyum Değerleri}

\begin{tabular}{|c|c|c|c|c|c|}
\hline Ölçüt & İyi Uyum & $\begin{array}{c}\text { Kabul } \\
\text { Edilebilir } \\
\text { Uyum }\end{array}$ & $\begin{array}{c}\text { Modelin } \\
\text { Uyum } \\
\text { Değerleri }\end{array}$ & $\begin{array}{l}\text { Uyum } \\
\text { Durumu }\end{array}$ & Kaynak \\
\hline$\left(x^{2} / s d\right)$ & $\leq 3$ & $\leq 4-5$ & 1,33 & İyi uyum & Byrne, 1989 \\
\hline RMSEA & $\leq 0,05$ & $0,06-0,08$ & 0,03 & İyi uyum & \\
\hline SRMR & $\leq 0,05$ & $0,06-0,08$ & 0,04 & İyi uyum & Browne ve Cudeck, 1993 \\
\hline CFI & $\geq 0,96$ & $0,90-0,95$ & 0,96 & İyi uyum & McDonald ve Marsh, 1990 \\
\hline PClose & $>0,05$ & $0,01-0,05$ & 0,99 & İyi uyum & $\begin{array}{l}\text { MacCallum, Browne ve } \\
\text { Sugawara, } 1996\end{array}$ \\
\hline GFI & $\geq 0,90$ & $0,89-0,85$ & 0,94 & İyi uyum & Tanaka and Huba, 1985; \\
\hline AGFI & $\geq 0,90$ & $0,89-0,80$ & 0,92 & İyi uyum & Jöreskog ve Sörbom, 1984 \\
\hline
\end{tabular}

Tablo incelendiğinde, tek faktörlü modelin, eldeki veriler ile iyi düzeyde uyum gösterdiği anlaşılmaktadır. Test edilen tek faktörlü model şekil 3’te gösterilmiştir. Ölçekte bulunan maddelerin faktör yükleri 0,44-0,60 arasında değerler almıştır. Modelde gösterilen tüm yol katsayıları istatistiksel olarak anlamlıdır $(p<0,001)$. Sonuç olarak, 
İç Kontrol, Risk Yönetimi ve Kurumsal Yönetim Süreçlerinin Değerlendirilmesine Yönelik Ölçeklerin Güvenilirlik ve Geçerlilik Çalışması

Kurumsal Yönetim ölçeğinin tek faktörlü yapısının eldeki veriler ile uyumlu olduğu anlaşılmıştır.

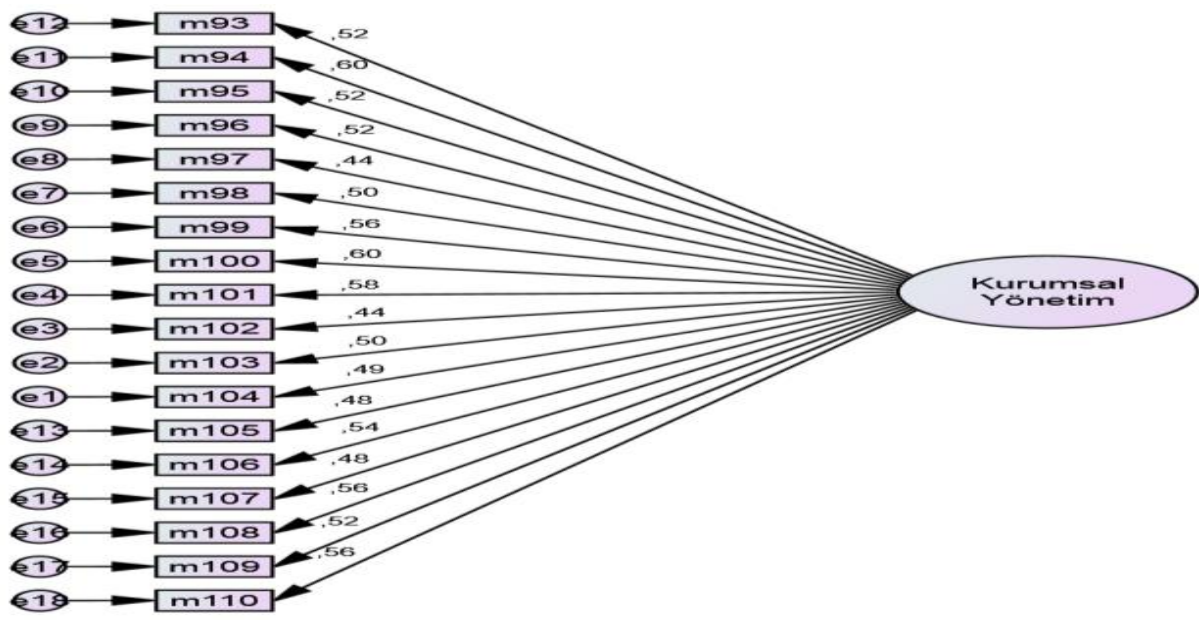

\section{Şekil-3 Kurumsal Yönetim Ölçeğine ait Doğrulayıcı Faktör Analizi Diyagramı}

\section{SONUÇ VE DEĞERLENDİRME}

Bu çalışmanın temel amacı; kurumsal risk yönetimi, kurumsal yönetim ve iç kontrol süreçlerinin hem iç denetim hem de yönetim tarafından değerlendirilmesine olanak verecek ölçekler oluşturmaktır. Organizasyonun güçlü bir kurumsal risk yönetim yapısı organizasyonun maruz kalacağı belirsizlikleri öngörerek yönetilmesi için gerekli tedbirlerin alınmasını gerektirmektedir. Kurumsal risk yönetimi organizasyonun karar alma süreçlerini destekleyen en temel argümanlardan biridir ve bu yaklaşımın kurumsal kültüre entegre edilmesi tüm paydaşların bu süreci benimsemesini ve organizasyonel risklerin de etkili bir şekilde yönetilmesini sağlayacaktır. Yönetişim süreci esasında bir "sorumlu karar" verme arayışıdır. Sorumlu karar verme arayışında karar vericiler verilen kararlardan tüm paydaşların etkileneceği bilinciyle hareket etmektedirler. Bu sorumluluk, etkileşen (stakeholder) ve paydaş hakları, etik, kurumsal amaçlar ve katılımcı/ortak akıl normlarından beslenerek verilecek kararı olgunlaştırmaktadır. Yönetişim sürecinin öngördüğü paydaşların tüm yönetim süreçlerine katılımı, paydaş katılımından kaynaklanabilecek problemlerle mücadele etmenin en güvenli yoludur (Lipton ve Lorsch, 1992, s. 64). İç kontrol sistemi hedef odaklı bir sistemdir ve operasyonel faaliyetlerin başarısında önemli rol oynadığı gibi kurumun stratejik amaç ve hedeflerine de ışık tutmaktadır. Stratejik yönetim, yönetim süreçleri, faaliyetler ve performans süreçleri ile ilgili tüm kontrolleri kapsayan iç kontrol süreci, ancak organizasyonun amaçlarını gerçekleştirmesine katkı sağladığında etkilidir denilebilmektedir (Pruvasi ve Ratrizia, 2015, s. 487). Yüksek kaliteli bilgi akışını öngören, organizasyon kültürünü hedeflerin başarılması için en önemli faktör olarak değerlendiren, personelin performansının değerlendirilmesini sistematik hale getiren bir iç kontrol sistemi, kurumsal hedeflerin başarılması için bir yol haritası sunmaktadır. 


\section{Göksel Korkmaz}

İç denetim, kurumsal risk yönetimi, iç kontrol ve yönetişim; organizasyonların varoluş nedenlerini sürdürmek ve hedeflerini gerçekleştirmek için kullandıkları yönetim araçlarıdır. Bu yönetim araçlarının ortak özelliği ise karar vericilerin organizasyonun geleceğine yönelik alacakları kararlara ışık tutmak, onları doğru yönlendirerek paydaşların menfaatlerini maksimize etmektir. Geleceğe yönelik belirsizliklerin ve risklerin minimize edilmesini, faaliyetlerin etkili ekonomik ve verimli yürütülmesini, organizasyonun karar süreçlerine paydaş katılımını öngören ve faaliyetlere değer katmayı temel ilke edinen bu yönetim araçlarının rasyonel etkileşimi sağlandığı takdirde, kurumsal amaçlara ulaşmak konusunda kurumsal güvence sinerjisi oluşturulabilecektir. $\mathrm{Bu}$ kurumsal güvence sinerjisinin hangi ölçüde yakalanabildiğinin belirlenmesi, alınabilecek önlemlerin ve gelişim alanlarının belirlenmesi ancak bu süreçlerin değerlendirilmesi ile mümkündür.Türkiye'nin en büyük 1000 işletmesinden 299'nda yapılan bu araştırmada öncelikle literatür taraması yapılarak uygun ölçekler bulunmuş, bu ölçekler Türkçeye çevrilerek güvenilirliği ve geçerliliği test edilmiştir. Söz konusu ölçeklerin gelecekte iç denetim ve organizasyonel süreçlerin etkililik değerlendirmelerine yönelik yapılacak çalışmalarda güvenle kullanılabileceği değerlendirilmektedir.

İç denetim konusundaki alan yazın oldukça kısıtlıdır ve iç denetimin organizasyona stratejik anlamda katkılarından ziyade, çoğunlukla iç denetimin organizasyona operasyonel ve finansal katkılarına yönelik yapılan çalışmalardan oluşmaktadır. Gelecekte yapılacak çalışmalarda, iç denetimin stratejik seviyede hangi süreçlere katkı sağlayacağının veya değer katacağının incelenmesinin iç denetim disiplinin geleceği açısından çok önemli olduğu değerlendirilmektedir. Bu rolün vurgulanması, iç denetim alanında çalışan kişilerin faaliyetlerine ışık tutarak hem yönetim kurulunun beklentilerine cevap vermelerine hem de kendilerine stratejik anlamda yüklenen misyonu sahiplenmelerine katkı sağlayacaktır.

\section{KAYNAKÇA}

Albercht, W.S., Howe, K.R.,Schueler, D.R. ve Stocks, K.D. (1988), Evaluating The Effectiveness of Internal Audit Departments, Instute of Internal Auditors, Altomante Springs, Florida

Agbejule, A. ve Jokipii, A. (2009), Strategy, Control Activities, Monitoring And Effectiveness, Managerial Auditing Journal Vol. 6 No. 24 , ss. 500-522.

AICPA (2016), The State of Risk Oversight: An Overview of Enterprise-Wide Risk Management Practices, North Carolina: The ERM Initiative in the Poole College of Management at North Carolina State University.

Bahrman, D. (2011), Evaluating ang Improving Organizational Governance, Florida: Altamonte.

Beasley, M., Pagach, D. ve Warr, R. (2008), The Information Conveyed in Hiring Announcements of Senior Executives Overseeing Enterprise-Wide Risk Management Processes, Journal of Accounting, Auditing and Finance 23(3), ss. 311-332.

Brickley, J.A. ve Zimmerman, J. (2010), Corporate Governance Myths: Comments On Armstrong, Guay and Weber, Journal of Accounting and Economics, ss. 235-245. 
İç Kontrol, Risk Yönetimi ve Kurumsal Yönetim Süreçlerinin Değerlendirilmesine Yönelik Ölçeklerin Güvenilirlik ve Geçerlilik Çalışması

Büyüköztürk, Ş. (2006), Veri Analizi El Kitabı, 6. Baskı. Ankara: Pegem A Yayıncılık.

Chapman, R. (2006), Enterprise Risk Management: Simple Tools and Techniques for Enterprise Risk Management. John Wiley\&Sons Ltd.

COSO, (2013). Internal Control-Integrated Framework, Comitte of Sponsoring Organizations (COSO).

Çokluk, O., Şekercioğlu, G. ve Büyüköztürk, G. (2012), Sosyal Bilimler lç̧in Çok Değişkenli SPSS ve Lisrel Uygulamaları, Ankara: Pegem Akademi Yayıncılık.

D'Aquila, J. (1998), Is The Control Environment Related To Financial Reporting Decisions, Menagerial Auditing Journal Vol. 13 No. 8, ss. 472-478.

Farrell, M. ve Gallagher, R. (2014), The Valuation Implications of Enterprise Risk Management Maturity, The Journal of Risk and Insurance 82, No. 3, ss. 625-657.

FERMA, (2003), A Risk Management Standard, Brüksel: Avrupa Risk Yönetimi Dernekleri Fedarasyonu.

Geiger, M.A. ve Cooper, M. (2004), Internal Control Components: Did COSO Get It Right?, CPA Journal, Vol. 74, Issue 1, ss. 28-31.

Grambling, A., Maletta, M., Schneider, A. ve Church, B. (2004), The Role Of The Internal Audit Function In Corporate Governance: A Synthesis Of The Extant Internal Auditing Literature And Directions For Future Research. Journal of Accounting Literature Vol. 23 No. 1, ss. 194-244.

Gürbüz, S. ve Şahin, F. (2016), Sosyal Bilimlerde Araştırma Yöntemleri, Ankara: Seçkin Yayıncılık.

Hermanson, D.R., Smith, J.L. ve Stephens, N.M. (2012), How Effective are Organizations Internal Controls? Insight Into Specific Internal Control Elements, Current Issues in Auditing, Vol. 6, No 1, ss. 31-50.

Hillson, D. (1997), Towards a Risk Maturity Model. International Journal of Project and Business Risk Management, ss. 35-45.

Holton, G. (2004), Defining Risk, Financial Analysis Journal, ss. 19-25.

Hoyt, R.E. ve Liebenberg, A., (2011), The Value of Enterprise Risk Management, Journal of Risk and Insurance, 78(4), ss. 795-822.

IIA, (2013), International Professional Practices Framework, Altamonte Springs, FL: (IPPF) The Institute of Internal Auditors.

IIA, (2016), Uluslararası Mesleki Uygulama Çerçevesi (UMUÇ), Florida: The Istitute of Internal Auditors.

Jones, M. J. (2008), Internal Control, Accountability And Corporate Governance Medieval And Modern Britain Compared, Accounting, Auditing \& Accountability journal, ss. 1052-1075.

Kosmala, W. M. (2014), Risk Management Practices from Risk Maturity Models Perspectives, JEEMS, 19(2), ss. 133-159.

Moeller, R.R. (2009), Brink's Modern Internal Auditing: A Common Body of Knowledge, New Jersey. Wiley.

Monda, B. ve Giorgino, M. (2013), An ERM Maturity Model, Presented at the: 2013 Enterprise Risk Management Symposium April 22-24, Chicago. 


\section{Göksel Korkmaz}

Muneeza, İ.A. ve Wajeeh, A. (2012), Strategic Corporate Governance For Sustainable Mutual Development, International Journal of Law and Management, ss. 197-208. Özbek, Ç. (2012), İç Denetim, İstanbul: Türkiye İç Denetim Enstitüsü.

Palermo, T. (2011), Managing Organizational Culture for Effective Internal Control From Practice Management, Managerial Auditing Journal, Vol. 21 No. 1, ss. 63-80.

Pickett, S. (2010), Internal Auditing Handbook, West Sussex: Wiley.

Porter, B., Simon, J. ve Hatherly, D. (2003), Principles of External Auditing, Wiley.

RIMS, (2011), An Overview of Widely Used Risk Management Standards and Guidelines, A Joint Report of RIMS Standards and Practices Committee and RIMS ERM Committee.

Sakarya, Ş. ve Kara, S. (2012), Kurumsal Risk Yönetimi Çerçevesinde Risk Odaklı İç Denetim ve IMKB Uygulaması, Ankara SMMO Muhasebe ve Vergi Uygulamaları Dergisi, ss. 69-95.

Sawyer, L. (2012), İç Denetçiler Için Rehber, İstanbul: Türkiye İç Denetim Enstitüsü.

Sawyer, L. (2016), İç Denetçiler İçin Rehber, İstanbul: Türkiye İç Denetim Enstitüsü.

Stringer, C. ve Carey, P. (2002), Internal Control Re-design: an Exploratory Study of Australian Organizations, Accounting, Accountability \& Performance, Vol. 8 No. 2, ss. 61-86.

Uzun, A. (1997), İç Denetimin Toplam Kalite Yönetimindeki Yeri ve Uygulamadan Örnekler, 6. Kalite Kongresi, Toplam Kalite Yönetimi.

Wilkinson, N. (2014), A Framework For Organizational Governance Maturity: An Internal Audit Perspective. University of Pretoria. 